\title{
Nicolás Varchausky, Eduardo Molinari (eds.), Tertulia. Intervención en el Cementerio de la Recoleta
}

Bernal, Universidad Nacional de Quilmes, 2016

\section{Miguel Garutti}

\section{OpenEdition}

\section{Journals}

Electronic version

URL: http://journals.openedition.org/transposition/5887

DOI: $10.4000 /$ transposition.5887

ISSN: $2110-6134$

\section{Publisher}

CRAL - Centre de recherche sur les arts et le langage

\section{Electronic reference}

Miguel Garutti, "Nicolás Varchausky, Eduardo Molinari (eds.), Tertulia. Intervención en el Cementerio de la Recoleta", Transposition [Online], 9 | 2021, Online since 15 January 2021, connection on 23 April 2021. URL: http://journals.openedition.org/transposition/5887 ; DOI: https://doi.org/10.4000/transposition. 5887

This text was automatically generated on 23 April 2021.

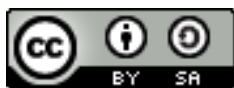

La revue Transposition est mise à disposition selon les termes de la Licence Creative Commons Attribution - Partage dans les Mêmes Conditions 4.0 International. 


\title{
Nicolás Varchausky, Eduardo Molinari (eds.), Tertulia. Intervención en el Cementerio de la Recoleta
}

Bernal, Universidad Nacional de Quilmes, 2016

\author{
Miguel Garutti
}

\section{REFERENCES}

Nicolás Varchausky, Eduardo Molinari (eds.), Tertulia. Intervención en el Cementerio de la Recoleta, Bernal, Universidad Nacional de Quilmes, 2016, 264 p.

1 In the 2000s, electroacoustic music created something new in Buenos Aires. Composers recognized in the tradition, at the time centered around the concerts of the Laboratorio de Investigación y Producción Musical (LIPM) ${ }^{1}$, were interested in including sounds and spaces as materials and scenarios in their works. Collaborating with artists from other disciplines, they took the speakers out of the concert hall. Works such as Intervención Pública \#1 (2002) and Tertulia (2005) by Nicolás Varchausky and Eduardo Molinari, and Mayo. Los sonidos de la Plaza by Buenos Aires Sonora (2003 and 2006) were among the first to address a mass audience, projecting the sounds from the archive over to monumental sites of the city. The composers set these site-specific works apart, retrospectively, cataloging them as "sound art". Most of the texts that seek to characterize this category allude to a specific type of listening attitude in the reception of these works, calling attention to the possibility of moving during the listening experience and the "historical and symbolic resonances" generated by the situated sound $^{2}$.A decade later, the University of Quilmes published a book on Tertulia, to inaugurate a new book series devoted to Sound Art, in its collection "Music and Sciences". Tertulia. Intervención en el cementerio de la Recoleta (2016), compiles a series of essays and documents and was edited by the artists themselves. 
2 Tertulia had caused a scandal. Announced as part of the Festival Internacional de Buenos Aires (FIBA), it consisted of a sound and visual "intervention" in the Recoleta Cemetery, situated in a traditionally elite neighborhood that holds the remains of well-known household historic names. Varchausky and Molinari proposed mounting loudspeakers, lights and backlighted images on 40 previously chosen graves. Each politician, sportsman, dictator, artist or intellectual had a loudspeaker and a three-hour long composition related to his or her biography. According to Varchausky, the combinations between materials were conceived from the possibility of generating four types of different relationships between the sounds and the characters: "biographical" (the character's voice, another voice representing him, his music or others composed for him), "genealogical" (future characters related), "surreal" (surprise, automatic, humorous) and "alchemical" (sounds of the elements of nature selected according to the date of birth of the character) (p. 39). The instants of synchronicity among all loudspeakers -handled, in the composer's view, as a choir from the Renaissancefeatured, among other sounds, an malón [an Indian raid] crossing the cemetery, the sounds of an execution by a firing squad, the Argentine National Anthem sung by schoolchildren, bells ringing and a battle bugle. The premiere had to be postponed by a court order championed by the "Friends of the Cemetery Association", self-proclaimed "vecinos notables" [illustrious neighbours], claiming that Tertulia represented a desecration of "their" deceased in a "theatrical" performance, as well as a "falsification of the collective memory"3:"Tertulia was not a work on history, but from history. Its aim wasn't a chronological or documentary narrative, it advocated for a plurality of voices, a crucible of stories" (p. 30). The authors confirm this in the book, that replicates the polyphonic interests of the work, through its compilation of testimonial and analytical texts from several writers.

3 The book is organized into three parts. "Más allá" [Beyond] gathers texts describing the project from an aesthetic and technical perspective, and was written by members of the production team -Pablo Chimenti and Hernán Kerlleñevich, who participated in the composition; Daniel Hernandez, the sound designer; and the light designer, Matías Sendón. It also features pictures from the montage process, the totality of Molinari's collected images that were distributed that night in backlit boxes throughout the cemetery, and a selection of the musical sounds, stored on a website that can be accessed by a QR code. The second part, "Más acá" [Nearby] is composed of thoughts, testimonies and images that recount the experiences of witnessing the exhibition, as well as the public debate that ensued. "Limbo", the last section, is an article in which Griselda Soriano recovers the most outstanding voices at the time Tertulia was announced. In this section, the artists' positions in the debate on history and memory, between neighbours and journalists, are articulated more clearly than in the other more testimonial essays. The media reception analysis by Soriano is joined by a section of sources -six pages of judicial and newspaper documentation- which will prove useful to readers interested in the production context. With the exception of "Limbo" and an article by Gabriel Di Meglio on the history of the cemetery, the texts in Tertulia are mostly reflections from the own experience of the artists, the producers and the spectators.

In "Más allá", the authors explain the premises of the work. The impossible dialogue between their both aristocrat and working-class ancestors was displayed in a labyrinthine cartography, where the power of sound generated the illusion of 
resurrection. This evocation of archive documentation was used for calling the ghosts to participate into a non-narrative fiction. The light design took a supporting role in enforcing the phantasmagorical experience on specific details of the darkened cemetery (p. 77). Backlit images and speakers were positioned in a way that favoured even stronger resonances.

Those concepts are tackled in the critical work and testimonials of the second part. Tertulia's device is described in an essay by Diego Sztulwark -in a clear reference to Borges' Aleph- as an "spherical viewpoint of the complete face of time, interrupting the already established and accepted hierarchies" (p. 176). Molinari narrates a fictional encounter between Legba, a voodoo spirit, and Norma Arrostito, a political activist kidnapped and killed by the military dictatorship in the late 70's (p. 209). Cristian Forte interprets this work as a pagan ritual guided by the audiences, which play the role of "mediums", becoming part of the story. Zambullista reads into the public's resistance to Tertulia, its eruption into the field of funerary art, "scandalously emancipated", sacrilegious, stripped of its ritual sense. Laura Gerscovich retells her experience as a member of the audience, referring to a "bilocation" of the space where both the dead and the living coexisted. Julián D'Angiolillo, who was in charge of audio-visual recordings, describes the incomprehension of the "illustrious neighbours" by narrating the visit of conservative journalist Mariano Grondona, who chose to elude the immersive experience of the setup, crossing the cemetery and the work while followed by his light and camera crew.

6 Both Varchausky's and Molinari's works gravitate around archive construction. Molinari's Archivo Caminante [Walking Archive] consists of a collection of images found in walks that he used to assemble his collages (p. 45). Many of the images present in Tertulia, and reproduced in the eighty-four black pages of the central section of the book, were found by chance in parallel searches that the artist undertook in the Nation's General Archive. Varchausky, for his part, collects sounds of voices and urban settings mostly recorded by himself: the Archivo PAIS. In one of his contributions to the book -"Archivo PAIS: cuatro hipótesis de trabajo"-, the composer explains his classification of these sounds, according to their place of origin (voices in a market, art, institutions, and religion) and explains his "work hypothesis" (p. 53). In his opinion, the human voice represents a musical material that carries a meaning. All sound, at the same time, is indivisible from the space where it has resonated, its "sense context". Sound, meaning and sense context mutually modulate themselves: the "symbolic resonances" that reside in the space are activated by the acoustic documents. The creative work, then, consists of analysing the tension between sound and meaning in recording the "spoken voice", while working on its capacity to frame and organize musical discourse. Varchausky claims to operate following the classification of listening attitudes that Michel Chion (L'audio-vision) synthesizes in his reading of Traité des objets musicaux by Pierre Schaeffer: the question about the causality of sound, the possibility or impossibility of decoding a semantic level in it, and its spectral qualities are the variables under consideration in his works.

7 Tertulia... is also a double album ${ }^{4}$. The forty-two tracks available online are a selection from the one hundred and twenty hours of audio that were heard that night -three hours for each of the forty graves. In each synchronicity, the voices were replicated in groups of loudspeakers, defining "zones" with the name of one or more characters. The albums are organized following this sequence, in general, with more than one track per 
zone. The great variety of characters is replicated by the diversity of ways of working with sound. Eva Perón recites, with an affected voice characteristic of Argentine classic cinema -very different from the fluidity that her political voice would reach-, all the lines of her character in a film where she was the protagonist and that, by order of Juan Perón, never premiered. Just before, we hear a version of Don't Cry for Me Argentina by Andrew Lloyd Weber, which superposes twenty-seven orchestral recordings. In another synchronicity, Borges recites fragments of war poems that allude to the combat of his ancestors against the indigenous of the pampas; on top of a loop of motifs from works by the nationalist composer Alberto Williams. Borges' voice will later re-appear reading fragments from The Golem in Williams' tomb ${ }^{5}$. In the background, two repeated chords stand out among several layers: television sounds, water, a school bell, extended piano techniques, etc. As in other tracks, distortions and repetitions, which at times articulate a beat, end up at a midpoint between electroacoustic and a hallucinatory ambient music. Similarly, Margaret Thatcher and General Galtieri declare their war speeches in an ostinato of voices from The House of Lords, in an hypnotizing lower register, repeating the word "Yeah". Nestor Perlongher pronounces a fragment of his poem Cadáveres [Cadavers]. His voice was also heard in an unintelligible and expansive mass composed of the forty verses of the poem, one for each speaker, which coincide in the last two words: "hay cadáveres" ["there are cadavers"]. The voice of Juan Manuel de Rosas -one of the most powerful men of Buenos Aires' nineteenth-century- instead, has a realistic treatment in the representation of given by writer Andrés Rivera, who reads a fragment of his book $\mathrm{El}$ farmer (1996), over sounds of the embers mentioned in the text. Finally, the last pages of Tertulia... include the list of musical tracks together with the description of the sound materials and who composed each.

Tertulia... is an unusual book about an unconventional work. The creation of works in large multi-channel systems represented a novelty in a scene that did not have concert halls dedicated to electroacoustics exceeding octophonic sound. The fact that they were made outdoors, incorporating techniques and materials of popular music, that their productivity was directly linked to the places in which they were presented, and that they went beyond the limits of the specific musical field resulted in an unprecedented impact on an unexpected audience. Tertulia was held at a time when the revision of history and the reconstruction of memory were topics present in the public sphere as well as in State policy. This was evidenced in both the interest and resistance that it generated. A testimonial catalogue of a single work, the book is another demonstration of the evocative power of archives. The details listed in the stories and photos of the registry, the careful reproduction of the original images and the edited sound -which can be freely accessed from any mobile phone- leave the reader with the feeling of having just walked through the cemetery that night. 


\section{NOTES}

1. The LIPM was inaugurated temporarily -although not under that name- in 1980 at the Centro Cultural Recoleta, then Cultural Center of the City of Buenos Aires, at the initiative of the composer José Maranzano (b. 1940), inspired by the Centre Pompidou. In 1984, a year after the return of democracy, a concert hall that had a quadraphonic system was inaugurated. The definitive installation of the laboratory, directed by Francisco Kröpfl (b. 1931) until 2006, concluded only in 1996. Since the mid-90s, the National University of Quilmes, in the outskirts of Buenos Aires, hosts the Composition with Electroacoustic Media Program, a work space for composers and technicians who began their career in the previous electroacoustic music centers -such as Fernando Reichenbach, Maria Teresa Luengo, Jorge Rapp, Pablo Cetta, Pablo Di Liscia, Oscar Edelstein and Carmelo Saitta. Martín Liut (1968) and Nicolás Varchausky (1973) are professors at that University.

2. VARCHAUSKY Nicolás and molinARI Emilio, Tertulia..., p. 17; LUUT Martín, "Música para sitios específicos: nuevas correlaciones entre espacio acústico, público y fuentes sonoras", BAsso Gustavo, LISCIA Pablo DI, PAMPIN Juan (ed.), Música y Espacio: ciencia, tecnología y estética, Bernal, Universidad Nacional de Quilmes, 2009, pp. 289-301; SAVASTA ALSINA Mene, "Music is not enough: the appropriation of the category of 'arte sonoro' in Argentina", RevistaMúsica, no. 1 , São Paulo, Universidade de São Paulo, 2020, p. 381-400.

3. Such was the title of the column written by the journalist Mariano Grondona in La Nación (07/25/2005), where he denounced "a retrospective aggression of the present against the past" launched by "improvised historians", "at the expense of the ingenuity of our youth". That same night he faced the artists of Tertulia in his television program. As Griselda Soriano analyzes that one of the reasons for Tertulia's being a provocation was the way it highlighted the mechanism of construction of history and memory, suspending certainties and presenting all interpretations as valid (p. 244).

4. The QR codes refer to the site http://tertulia.blog.unq.edu.ar/, consulted on 17 July 2020.

5. The presence of Borges orbits most of the essays in the book. In the program that was handed out to the public, a quote from El Aleph is also included (p. 41).

\section{AUTHORS}

\section{MIGUEL GARUTTI}

Miguel Garutti is PhD Candidate on Historia y Teoría del Arte at the University of Buenos Aires (UBA), tutored by Pablo Fessel. He's graduated in Artes at UBA and also studied music composition and technology at the National University of Quilmes (UNQ) and University of Sao Paulo, Brazil. His thesis explores the relations between electroacoustics music and politics at the 70s in Buenos Aires. He also works as an assistant in the Fernando von Reichenbach at the UNQ as 
well as researcher at the Laboratorio de Investigación y Producción Musical of the Centro Cultural Recoleta. He has participated in numerous artistic and scientific meetings, including the organization of the international congress Teatro Instrumental. Música y Escena en América Latina (1954-2006) in 2018 in Buenos Aires. 